spleen full of blood; it contracts; there are no valves at the entrance of the splenic artery, therefore part of the arterial blood would attempt to return up that vessel, in direct opposition to the heart's impulse. But as to the greater portion of the fuid, it would pass along the splenic vein to the junction of the superior mesenteric; and as there are no valves at the entrance of that vessel, it would be driven two ways, partly into the mesenteric veins, in direct opposition to the general circulation, and partly up the portal vein to the liver. Such an arrangement would be almost as useless as the left ventricle of the heart acting without a mitral valve. I remain, Sir, yours obediently,

Liil toa-Lindsey, Feb. 1550. II. J. WaterLAxD.

\section{THE COUNCIL OF THE COLLEGE OF SURGEONS.} To the Editor of 'THE LANCET.

$S_{I R},-I t$ is to be regretted that the opportunity offered by the delivery of the IIunterian Oration, once in every year, should not be made, as was intended by the illustrious founder, a source of profit, and the means of cementing the combined interests of our noble profession! This year it was preceded, purposely, I should inagine, by an announcement from the Council of a most unjust and illiberal lind, intended, no doubt, to test the feelings of the members; offering them a stone as a substitute for bread. When $I$ couple the insincere and offensive language of the orator, $I$ am at a loss to conceive what deductions were anticipated, and what expectations realized; if the symbol of the College, as to the future, is to be a withered olive-branch, and the anchor of hope, broken, the members will vote it unanimously. They will also add a broken lute, as an insignia of the discord and want of harmony which pervade its edicts and incantations. The Council, I should think, are not musical, or they would remember the fate of Orphens, who, it is said,-

$$
\text { " But now moves nothing but his fiddle stick." }
$$

It is quite evident, however, that the perfections of the highest order of minds are unknown to the Council! despite the anuual recital and commenoration of departed virtue and acquirements, which wa i received with the usual marked respect on the present occasion, though it was quite evident there was something in subjection, and that something was the noble science, which has been so long fettered by conservative principles, which, in these days of civilization, free trade, and reform, can no longer resist the pressure of her true rotaries. It is foreign to my purpose to review, critically, the peculiar phases of an oration, intended to illustrate the bright deeds and characters of the departed; yet I cannot refrain expressing my sontiments at the mockery held out to the living.

My motive for addressing you, Sir, is to call forth, if it exist, the expiring scintillation, the last dying glimmer of good faith, from the heads or hearts of those satellites, who are revolving round the shadows, not the substance, of the mighty and regretted planets, whose memory we venerate, and whose abscnce we annually meet to deplore.

It has of tentimes been asked-What do the members require? I will now state what it appears to me we require. First, an extension of the collegiate franchise, in order that surgeons in general practice may possess the right of election to the council. I would also submit, that all students in medicine and surgery (for they cannot be separated) be admitted at a certain age, say eighteen or twenty, before they commence anatomy and surgery, to their examination in the classics, mathematics, languages, \&c., giving each successful candidate a certificate of qualification on these points, thereby disburthening their minds and improving the whole class of medical practitioners, without placing the burthen on the fellows only; in after years, their diploma to practise would be the result of future studies and theindustry exercised. As regards the council, their prodigal and unnatural bearing towards us, their own offspring, is monstrous, and, like the sin of the giants, as expressed by 'Tully, "is an actual rebellion against heaven." The generality of "your readers will recollect the information given by Homer, when Minerva removed the mist from the eves of Diomedes, in order that he might plainly distinguish both gods and menin other words, that he might discern the good from the evil. All will, no doubt, feel it their duty to call up their best efforts to operate gratuitously in removing the cataract which has become permanent in the optical delusions of the council. Oh! that they possessed the soul to exclaim, with Alcibiades, "Remove from my mind the darkness, or whatever else that obscures it; I will refuse nothing, so that I become a better man." Can modern generals or philosophers say more? Will advancement in knowledge and science say as much. Whether we are medical or legal practitioners, we must not forget that we are men-responsible, reasonable, Christian men. I would refer your readers to the tenth satire of Juvenal, and the second of Persius, which afford to the curious some interesting arguments, demonstrative of the feelings of the most refined heathens. I quote the first passage, translated by Dryden, of Juvenal's tenth satire:-
"Look round the habitable world-how few
Know their own good, and knowing it, pursue ',
I am, Sir, yours obliged, William SETh Gint.

Colebrook-tcrrace, Isiington, Feb. 25, 1850.

\section{THE JOHN HUNTER CLUB.} To the Editor of The Lancer.

SIR,-Touching the election for the secretaryship of the Royal Medical and Chiruraical Society, allow me to say, that it appears to me that Mr. Charles Hawkins has been rather hardly dealt with, being made to bear all the odium attaching to the "John-Hunter Club." I was not a member myself, but $I$ have heard that it comprised among its members a very considerable number of "Fellows." Now, I think it but fair that we should learn the names of the other members, that we may at least mete out the same measure of justice to cach that Mr. Charles IIawkins has received. Perhaps you can furnish the names. But I conclude that the gentlenen who composed the club, as they have declared they wished not for secresy, will send you their names; or perhaps Mr. Charles Hawkins, who was secretary, will furnish you with a list. I cannot be lieve what I have heard, that Mr. Erichsen was a member of the club, and lent limself to the opposition to Mr. Charles Hawkins, and was silent on this subject; and as I think Mr. Erichsen ought to have an opportunity to clear himself from the supposition, $\mathrm{I}$ consider that the names of the members of the Joln-Hunter Club should be made public. I am, Sir, yours \&c., Fiat Justitia.

* We are not in possession of the names of the members of the John-Hunter Club. If the list be sent to us, it shall be published for the information of the profession. We do not believe that Mr. Erichsen was a member of the club.-ED $L$.

\section{THE MEDICAL PROFESSION AND THE ASSURANCE OFFICES.}

To the Editor of THE LANCET.

The Industrial and General Life Assurance and Deposit Company, 2, Waterloo-place, London, Feb. $28,1850$.

SIR, - Mry attention having been called to your corvespondent's letter on the $23 \mathrm{rd}$ instant, I consider it necessary to trouble you with the following remarks, being of opinion, that, without additional information, the profession cannot fairly judge as to the propriety of accepting the fee of $2 s .6 a$. therein referred to.

This company has been established with the view of extending the benefits of life assurance to the industrial classes, by inculcating habits of saving, and affording them opportunities of making provision for their wives and families, hitherto unattainable by that large and important class-thus,

By a weekly payment of 1 s., a person twenty years of age may assure $11493 \mathrm{~s}$. If thirty years of age, $\pm 118 \mathrm{~s}$.; and if forty years of age, $£ 89 \mathrm{Ts}$, , to be paid to their families at death. By a monthly payment of $1 s$, a person twenty years of age

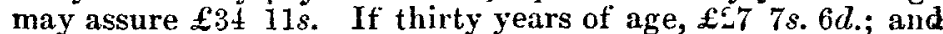
if forty years of age, $£ 2013 s .6 d$., to be paid to their families in like manner.

By a quarterly payment of $1 s$, a person twenty years of age may assure $\mathfrak{E} 11$ 12s. $6 \mathrm{l}$. If thirt $y$ years of age, $£ 94 \mathrm{~s} .9 \mathrm{l}$.; and if forty years of age, $£ 619 s$, to be in like mauner paid at deatl..

Under the " deposit" or " accumulative" system also,

A person, aged twenty, on payment of $\mathfrak{f}_{3} 9 \mathrm{9} .9 \mathrm{~d}$. will receive a policy, assuring $£ 10$ at death, (on which policy no further payment whatever is required, and after the first year may receive back $£ 39 s$. 9d., or after the sixth year, $£ 3158.2 d$, as shown in table, and surrender the policy; or may borrow the full amount of premium paid at the usual interest, on security of the policy only, repaying the loan at convenience.

The directors coincide in opinion with your correspondent, 
that the medical referees onght to be remunerated by the office, and they consequently allow the usual fee of one guinea when the preniums are not payable weekly or monthly, and the sum assured exceeds $£ 100$; but considering that on several of the smaller policies a few shillings only may be obtained, the directors trust the profession will concur with them in opinion, that the fee offered is as much as they can with propriety afford.

I have much plcasure in being able to state, that several of our medical referees, regarding the examination in such cases as a matter of benevolence, have intimated their intention of appropriating such fees towards the first payment under the policy, as an additional inducement to the industrial classes to avail themselves of the advantages now offered to them by the establishment of this company.

I remain, Sir, your most obedient servant, Wr. THos. Woops, Resident Director.

THE SCOTTISH EQUITABLE.

To the Editor of The LanceT.

SIR,--Your pages have lately contained much correspondence between medical men and assurance offices, relative to the paying or withholding the honorarium for filling up the medical certificate. Let me report the liberal conduct of the Scottish Equitable. I was requested by the agent to examine a patient of mine, and send my opinion in the usual form of reply to questions. This was afterwards sent to the medical referee of the office, who also examined the person, and made his report. The agent met me a few days after in the street, and very unexpectedly put a guinea into my hand, having satisfied their own referee as well. In thirty years' practice, I do not recollect to have experienced so liberal treatment.

Bucks, March 5.

W. S.

\section{THE UNITY OF MEDICINE-THE ONE-FACULTY SYSTEM. \\ To the Editor of The Lancers.}

Sin,-In undertaking to uphold the unity of medicine, or the one-faculty system, as it has been called, I am fully aware that I have undertaken a responsible dnty.

The present want of system and unity in the profession is represented by powerful and learned colleges-colleges which have excited the admiration of past generations; which now command the attention of the Government, and which have attracted to them some of the wisest and best men of which the profession of medicine in modern times can boast. There is, then, besides the prestiges which belong to objects pronounced venerable by time, the reality of these institutions to be dealt with, and the opposition of their interested supporters to overcome.

The respective interests of existing medical institutions are very frequently conflicting; and often, individually and collectivelr, they clash with the public weal. My Lord Melbourne declared in the House of Lords, on the 13th of May, 1833, " that most of the difficulty of the subject (medical reform) arose from conflicting interests." And conflicting interests then succeeded, and the $y$ have ever since succeeded, in warding off the impending reform. But come the reformation will, in spite of all conflicting interests, and it will only be the more searching and complete for the length of time it has been delayed.

On the 25th of May, 1833, you, Sir, declared, in The Lancer, in one of those powerfui leaders which hare made your journal known and valued thronghout the world, tbat " by the institution, upon a just and comprehensive foundation, of a Faculty of Medicine for each of the three kingdoms, each enjoying like privileges, each securing like competency of miedical attainment in practitioners, and all holding ont the like friendly support to the scientific inves igator, the law would be made to harmonize throughout the United King:lom, existing anomalies would be abolished, and the practice of medicine secured on a basis which would lead to the production of the greatest national advantages."

These sentiments, Sir, inspired me with their truth when they were written, and seventeen rears of observation has confirmed me in the conviction that they must he put in practice before there will he any rest for the profession.

Although the present want of system and unity is upheld by the colleges, and their "conflicting interests," I have such faith in the really great men in our profession, that I feel certain they bave only to be convineed that one system of government for the whole pro'ession would be for the public good, to make them come forward to relinquish any individual and special privileges they might have been unduced to obtain, or which "the wisdom of our ancestors" had forced them to accept. It is not from the truly great men in our profession, but from its parvenu aristorracy, that we may expect the greatest opposition to the one-faculty system. It may, then, be as well to allay the anger, and quiet the fears of these gentlemen-German doctors and all-by letting them clearly understand at once, that the reform we seek is not a question of resigning rights and privileges, or of demanding them; for, as I once before said, in a letter on this subject, legis. lation has done its best and its worst for us. All new laws to be just must be prospective in their operation. And no law can be permanent without being just. What is to be done by the legislature must be done for the future. We have not then, in trutb, the least occasion to let our personal interests or feelings enter into the discussion of this question. The only question before us is, What laws affecting the future practitioners of medicine will be best for the public? Is it for the public good that things should remain as they are, or can we inprove the profession of medicine by legislating for those who are in future to practise the art of healing?

Had it not been acknowledged, over and over again, on all sides, both in the profession and out of it, that the laws relating to the practice of medicine are defective-that some change is absolutely required-it would have been necessary, before going further, to have examined that question. But time after time it has been proclaimed to the world in the most public manner. One government after another has wimessed to this fact by attempting to provide a remedy; but time after time the inefficient remedy has been put aside, and the disease remains uncured.

Luckily, time works wonders.

It is the nature of the remedy, then, we have to inquire into; and we might be thankful that we are spared any examination into the nature of the disease, rid we not most acutely feel how thoroughly its manifold symptoms are exposed to the public gaze. One favourable sign, however, exists. We have not absolutely stoc $d$ still, while all the world has been progressing. But it is the fashion for those who wish to keep things as they are to talk of degeneracy, not thinking for a mument, ir their condemnation was true, it would be one of the most favourable arguments that could be adduced in favour of a change. But I verily believe there is not a man among us who does not strive after improvement; who does not sincerely desire to see his successor more learned than himself. The great efforts now heing made for reformation, indeed, prove that it is so. And we may assert, without fear of contradiction, that our profession does not eontain within it a man who would advocate, either in public or private, a return to " the good old times" of the red fillet and barber's pole. 'These retrogade movements, happily, are not advocated by our profession; but are reserved as a monopoly for the monkish crew who have no faith in the gradual improvement of their race; and for the bigoted curer of souls who sees in that improvement an utter annihilation of his craft.-I am, Sir, very obediently yours, Oxford-terrace, Hyde-park, March 2, 1850. William Robins.

\section{A DESCRIPTION AND DELINEATION OF AN EXTRAORDINARY MACHINE FOUND IN THE VAGINA.}

\section{To the Editor of The Lancet.}

Srr,- Some time ago, a lady came to London in a wretched state of health. She complained of constant and excruciating pain in the region of the uterus, and there was profuse and offensive discharge from the vagina. The patient stated, that eight months before, she had consulted an accoucheur, who told her that "she was labouring under retroversion of the uterus, and that all her bowels were out of place." Believing that her womb was completely turned topsy-turvy, and that all her viscera were displaced, she consented to have an instrument introduced, which, the accoucheur confidently as. sured her, would restore everything to its natural position, and would not prevent her from riding on horseback, or even undertaking a voyage to India. The introduction of the in. strument, she said, caused violent pain, but it was not once removed during eight months, though she had been in a state of constant suffering, had profuse fotid discharge, with sickness at stomach, and great constitutional disturbance. When an examination was made, the finger came in contact with a foreign body in the vagina, which was removed, with great difficulty and pain, in a black, half-rotten state. The vagina and uterus were found to be extensively ulcerated.

The following is a description and delineation of this extraordinary machine. It consists of a compressed oval ring, of German silver, in a black, corroded state, two inches and a half in length the long diameter, and one inch and a quarter in the short diameter; the perpendicular length or breadth of 